Landslides (2018) 15:995

DOI 10.1007/s10346-018-0983-3

Published online: 2 April 2018

(c) Springer-Verlag GmbH Germany,

part of Springer Nature 2018

\author{
Guruh Samodra - Danang Sri Hadmoko - Ghalih Nur Wicaksono - Indriya Parahita Adi · \\ Maulana Yudinugroho - Sandy Budi Wibowo - Hatma Suryatmojo - Taufik Hery Purwanto \\ Barandi Sapta Widartono · Franck Lavigne
}

\section{Correction to: The March 24 and 29, 2016 landslide-induced debris flow at Clapar, Banjarnegara, Central Java}

Correction to: Landslides

$$
\text { https://doi.org/10.1007/s10346-018-0958-4 }
$$

The published version of this article, unfortunately, contained error. Below have the items from the original paper to be corrected.

Article Title

From "The March 25" to "The March 24"

Abstract

“24 March 2017" to "24-25 March 2016”

“29 March 2017" to “29 March 2016”

Landslide Description

"24 March 2017" to "24-25 March 2016"

“29 March 2017" to “29 March 2016”

Figure 3 caption

“1 March - 10 April 2017" to "1 March - 10 April 2016”

Figure 5 caption

"March 23-30, 2017" to "March 23-30, 2016"

Figure 9 caption

“24 March 2017” to “24 March 2016”

Discussion

"traditional fishponds (Fig. 3c)." to "traditional fishponds (Fig. 4c)."
Last paragraph before Conclusion

"the March 25 and 29, 2016" to "the March 24 and 29, 2016"

The online version of the original article can be found at https://doi.org/10.1007/s10346018-0958-4

G. Samodra (- D ) D. S. Hadmoko - G. N. Wicaksono - I. P. Adi ·

M. Yudinugroho

Department of Environmental Geography, Faculty of Geography,

Universitas Gadjah Mada,

Yogyakarta, Indonesia

S. B. Wibowo - T. H. Purwanto - B. S. Widartono

Department of Geographic Information Science, Faculty of Geography, Universitas Gadjah Mada,

Yogyakarta, Indonesia

H. Suryatmojo

Laboratory of Watershed Management, Faculty of Forestry,

Universitas Gadjah Mada,

Yogyakarta, Indonesia

\section{F. Lavigne}

Laboratoire de Géographie Physique, Université Paris 1 Panthéon-Sorbonne,

Meudon, France
Email: guruh.samodra@ugm.ac.id 